\title{
A review of embryonic mortality in cattle
}

\author{
N. Ayalon \\ Department of Reproduction, Kimron Veterinary Institute*, Beit Dagan, Israel
}

\section{Introduction}

Embryonic mortality, strictly interpreted, should refer to fertility losses during the embryonic period, i.e. the period extending from conception to completion of the stage of differentiation which, in the cow, occurs at approximately 45 days (Committee on Reproductive Nomenclature, 1972). However, many authors have included under this term, fertilization failure, as well as death after fertilization. Since the present review was written for presentation within the framework of a symposium on reproductive efficiency in domestic animals, it was considered necessary to include data on fertilization rates, for a more complete picture of fertility losses.

Many reviews have been written dealing with embryonic mortality in farm animals and those concerned with cattle include papers by Laing (1952), Casida (1956), Hanley (1961), Ayalon (1964), Boyd (1965), Jainudeen (1965) and Vandeplassche (1968). The present review is meant to emphasize newer information bearing upon fertility losses in cattle.

\section{Methods of Study}

\section{Breeding records}

It is widely considered that an increase in the interval between service and return to oestrus beyond the usual range of 17-25 days reflects embryonic mortality (Erb \& Holtz, 1958). This is supported by observations, such as those of Marion, Smith, Wiley \& Barrett (1950) that mating with a vasectomized bull had no significant effect on the subsequent time of return to oestrus; and those of Boyd (1973) who found a significant difference in intervals between periods of oestrus before and after first inseminations: $90 \%$ of preinsemination cycles were of normal length, as compared with only $43.5 \%$ of postinsemination cycles. The difference between non-return rates up to 3 months and actual pregnancy diagnosis is, of course, well known, and delayed returns due to unobserved oestrus is a common problem in large dairy herds. Despite this there are strong objections to using increased intervals between insemination and return to oestrus, as the chief evidence for embryonic death, for at least three reasons. (1) Cows which had not been in oestrus may have been inseminated. Estimations of progesterone levels in blood (Appleyard \& Cook, 1976) and in milk (Hoffman, Gunzler, Hamburger \& Schmidt, 1976) have shown that up to about $20 \%$ of cows presented for insemination were probably not in oestrus. (2) Uterine inflammation or infection, which can occur after insemination, is associated with persistence of the corpus luteum and with delayed returns to oestrus (Ginther, 1968b). (3) The major portion of embryonic losses occurs well before Day 15 after service (Ayalon, Weis \& Lewis, 1968; Boyd, Bacsich, Young \& McCracken, 1969; Ayalon, 1972), and therefore the embryo dies too early to prevent secretion of the uterine luteolysin (prostaglandin) which causes regression of the corpus luteum and thus the dramatic decrease in progesterone levels (Ginther, 1968a; Hansel, Concannon \& Lukaszewska, 1973) which precedes the return to oestrus. Such cows will therefore return to oestrus after the same interval as unmated animals, despite their having been pregnant. 


\section{Planned slaughter after breeding}

This approach has yielded the most reliable information about the nature of fertility losses. Since the early reports of Laing (1949) and Tanabe \& Casida (1949), a series of investigations have been carried out, to examine fertilization rates about 3 days after mating and subsequent embryonic mortality at different times, usually up to 35 days after mating. Table 1 summarizes the results of a number of investigations up to 1969 in normal and repeat-breeder heifers and cows, after impregnation with semen from fertile bulls. Several findings stand out from these results. (1) In first-service heifers, the fertilization rate achieved may be almost $100 \%$. Fertility losses in these animals are due almost solely to embryonic death. (2) In repeat-breeder heifers, heavy fertility losses occur because of fertilization failure and also embryonic mortality. (3) Cows with normal breeding histories also sustained fertility losses due to fertilization failure and embryonic death, but both were at low levels. (4) Repeat-breeder cows suffered fertility losses due to fertilization failure and embryonic mortality, both at higher levels than in normal cows, resulting in total fertility losses twice as high as those in normal cows after about 5 weeks after insemination.

Table 1. Fertility losses in heifers and cows

\begin{tabular}{|c|c|c|c|c|}
\hline $\begin{array}{l}\text { Type of cattle } \\
\text { and reference }\end{array}$ & No. of animals & $\begin{array}{c}\text { Fertilization failure } \\
(\%)\end{array}$ & $\begin{array}{c}\text { Additional } \\
\text { embryonic loss to } \\
35 \text { days } \\
(\%)\end{array}$ & $\begin{array}{c}\text { Normal embryos } \\
\text { at } 35 \text { days } \\
(\%)\end{array}$ \\
\hline \multicolumn{5}{|l|}{ First-service heifers } \\
\hline Bearden et al. (1956) & 58 & 3.4 & $10 \cdot 5$ & $86 \cdot 1$ \\
\hline Kidder et al. (1954) & 32 & $\mathbf{0}$ & $24 \cdot 2^{*}$ & $75 \cdot 8^{*}$ \\
\hline \multicolumn{5}{|l|}{ Repeat-breeder heifers } \\
\hline $\begin{array}{l}\text { Tanabe \& Almquist } \\
\text { (1953) }\end{array}$ & 200 & $40 \cdot 8$ & $28 \cdot 7$ & $30 \cdot 5$ \\
\hline \multicolumn{5}{|l|}{ Normal cows } \\
\hline Ayalon (1969) & 114 & $17 \cdot 0$ & $14 \cdot 0$ & $69 \cdot 0$ \\
\hline Boyd et al. (1969) & 112 & $15 \cdot 0$ & $15 \cdot 0$ & $70 \cdot 0$ \\
\hline \multicolumn{5}{|l|}{ Repeat-breeder cows } \\
\hline $\begin{array}{l}\text { Tanabe \& Casida } \\
\text { (1949) }\end{array}$ & 104 & $39 \cdot 7$ & $39 \cdot 2$ & $21 \cdot 1$ \\
\hline \multirow{2}{*}{$\begin{array}{l}\text { Hawk, Wiltbank, Kidder } \\
\text { \& Casida (1955) }\end{array}$} & 100 & Not examined & $47 \cdot 0$ (16 days) & \\
\hline & & & $72 \cdot 0$ (34 days) & $28 \cdot 0$ \\
\hline Ayalon (1969) & 129 & $29 \cdot 0$ & $36 \cdot 0$ & $35 \cdot 0$ \\
\hline
\end{tabular}

* Based upon 60-90 day non-returns to oestrus.

Fertility losses, for periods between 3 and 19 days after service have been examined in a comparative investigation of various parameters connected with the reproductive performance of normal and repeat-breeder cows (Ayalon et al., 1968; Ayalon, 1972) and the results are shown in Table 2.

Since it was clear that embryonic deaths in repeat breeders were occurring no later than 11-13 days after insemination, it was decided to examine fertility losses at earlier times. The fertility findings (Table 3) were not significantly different between the two kinds of cows until Day 6-7 after insemination. Within the repeat-breeders group, highly significant differences $(P<0.01)$ were evident between the results at 4-5 days and later periods. Altogether, these results furnish clear evidence that fertility losses in repeat breeders occur earlier than previously considered. The critical period appears to be soon after the embryo enters the uterus, 6-7 days after service, when the morula is developing into the blastocyst. Ayalon (1973) has shown that Day 7 rather than Day 6 is the critical day on which embryonic death becomes evident. 
Table 2. Fertility losses (as embryos found/cows slaughtered) in dairy cattle after mating

\begin{tabular}{|c|c|c|c|c|}
\hline \multirow[b]{2}{*}{ Time of slaughter (days) } & \multicolumn{2}{|c|}{ Normal cows } & \multicolumn{2}{|c|}{ Repeat-breeders } \\
\hline & No. & $\%$ & No. & $\%$ \\
\hline 2-3 days* & $10 / 12$ & $83^{\circ}$ & $12 / 17$ & $71^{c}$ \\
\hline $11-13$ days & $16 / 18$ & $89^{a}$ & $9 / 18$ & $50^{\circ}$ \\
\hline 14-16 days & $16 / 20$ & $80^{a}$ & $10 / 20$ & $50^{b}$ \\
\hline 17-19 days & $12 / 21$ & $57^{a, d}$ & $9 / 21$ & $43^{b}$ \\
\hline $35-42$ days & $9 / 13$ & 69 & $8 / 24$ & $35^{d}$ \\
\hline
\end{tabular}

Values with an $a$ or $c$ superscript are significantly different $(P<0.05)$ from those with a $b$ or $d$ superscript respectively.

* These values are for fertilized ova/ova recovered.

Table 3. Fertility losses (as no. of normal embryos/embryos found) in dairy cattle early after service

\begin{tabular}{|c|c|c|c|c|}
\hline \multirow[b]{2}{*}{ Time of slaughter (days) } & \multicolumn{2}{|c|}{ Normal cows } & \multicolumn{2}{|c|}{ Repeat-breeders } \\
\hline & No. & $\%$ & No. & $\%$ \\
\hline 4-5 days* & $22 / 25$ & 88 & $20 / 25$ & $80^{c}$ \\
\hline 6-7 days & $10 / 12$ & $83^{a}$ & $5 / 12$ & $42^{b, d}$ \\
\hline $8-10$ days & $13 / 18$ & $72^{a}$ & $9 / 18$ & $50^{b, d}$ \\
\hline
\end{tabular}

Values with an $a$ superscript are significantly different $(P<0.05)$ from those with a $b$ superscript. Values with a $c$ superscript are significantly different $(P<0 \cdot 01)$ from those with a $d$ superscript.

* 5 days after service $=$ about $90 \mathrm{~h}$ after ovulation.

\section{Etiological and influencing factors}

With slight modification, we have adapted Boyd's classification (1965) of factors for embryonic death into two main classes: (a) genetic factors-breed, family, inbreeding and blood groups, and (b) environmental factors - nutrition, age, climate, infections, hormonal imbalance and uterine environment.

\section{Genetic factors}

No significant differences in the incidence of embryonic mortality were found between HolsteinFriesian and Guernsey cattle (Casida, 1950). Neither were there significant differences, up to 150 days of gestation, between inbred or outbred embryos or inbred or outbred dams (Hawk, Tyler \& Casida, 1955). By contrast, Mares, Menge, Tyler \& Casida (1961) and Conneally, Stone, Tyler, Casida \& Morton (1963) noted that inbred dams had a lower incidence of embryo survival.

Genetic variability for conception at first service and embryonic mortality was found among different families of Holstein-Friesians in the U.S.A. (Mares et al., 1961; Menge, Mares, Tyler \& Casida, 1962). Inbreeding influenced embryonic mortality at different levels-early when the embryos were inbred, and later when the dam was inbred. Casida (1961) reported that daughters of dams conceiving at first service, compared with daughters of dams who did not, had higher conception rates themselves at first service, but suffered a higher rate of embryonic mortality. 
Ashton \& Fallon (1962) appeared to show, on the basis of returns after 25 days from artificial insemination, that matings between cattle homozygous for beta-globulin showed a good fertilization rate but also considerable embryonic death. However, Rausch et al. (1963) found no correlation between fertility and beta-globulins. Infertility, due to a high incidence of embryonic mortality, was induced in heifers isoimmunized with a single injection of semen (Menge, 1969). Chromosome abnormalities were detected by the presence of tetraploid cells in 1 of 8 blastocysts, 12-16 days old, by McFeely \& Rajakoski (1968), and it was considered that chromosome abnormalities might contribute to early embryonic mortality in cattle.

An interesting theoretical approach to the question of genetic involvement in embryonic death was presented by Bishop (1964). He suggested that the genetic factors involved in embryonic mortality are not necessarily inherited by the parents but rather that most of these factors arise de novo in each parent generation and that some are likely to arise in the definitive gametes. Bishop contended that a considerable part of embryonic death is unavoidable and should be regarded as normal and as a means of eliminating unfit genotypes at low biological cost.

\section{Environmental factors}

Nutrition. There are practically no experimental data on the correlation between nutrition and proven embryonic mortality. Most pertinent experiments concerning nutrition and fertility deal with the influence of the plane of nutrition. In a long-term experiment with Holstein-Friesian cattle, lasting from birth until the 5th calving (Reid et al., 1964), the reproductive performance was compared of cows fed low, medium or high planes of nutrition from birth to the time of first calving; after which the plane of nutrition was equalized. Feeding level had no significant effect on the number of services per pregnancy up to the 6 th pregnancy. The percentage of first pregnancies was related inversely to the plane of nutrition provided before the first calving. There are other reports which indicate an adverse effect of a high plane of nutrition on fertility in heifers (Brännäng, 1954; Joubert, 1954). In a lifetime experiment, Larsen \& Larsen (1956) found that the level of feeding imposed after the first calving had very little effect upon the number of services needed per pregnancy, although there was a tendency for cows on a low nutritional plane to conceive more readily than those on higher planes.

Reid et al. (1964) emphasized that it has not been determined whether fertilization or embryo survival in cattle is influenced by feeding level. In one of the few nutritional experiments connected with fertility in which planned slaughtering was employed (Hill, Lamond, Henricks, Dickey \& Niswender, 1970), beef heifers were subjected to short-term undernutrition. Fertilization rate and embryonic survival were compared with those in beef heifers fed the same diet but at normal levels of energy and protein. Undernutrition reduced plasma levels of progesterone and reduced the proportion of heifers with normal fertilized ova. No clear effect was seen on embryonic mortality at 8 or 18 days after breeding. Broster (1973) reviewed liveweight change and fertility in lactating dairy cattle, and the effects on fertility of protein and energy variations in the diet, yield level, feeding time around service and overfeeding. He concluded that the relationships were poorly defined and required further investigation.

Age. Based upon intervals of return to service, Erb \& Holtz (1958) concluded that heifers had a higher rate of embryonic death than cows of fourth or fifth parity.

Climate. Most publications dealing with climate and reproduction consider the effect of high temperatures on fertility in cattle, and the cow rather than the bull is the major contributor to the seasonal (late summer) infertility (Stott, 1961). Late summer infertility was characterized by a low rate of pregnancy at 35-41 days, and delayed returns to oestrus. It appeared that most embryonic losses occurred before 35 days (Stott \& Williams, 1962). Thermal stress after mating had disastrous effects on beef heifers exposed to $32^{\circ} \mathrm{C}$ for $72 \mathrm{~h}$ immediately after insemination; none of the animals became pregnant compared with a $48 \%$ conception rate in heifers exposed to $21^{\circ} \mathrm{C}$ (Dunlap \& Vincent, 1971). In dairy cows the first 4-6 days after service were determined to be the most critical (Wiersma \& Stott, 1966, 1969). Plasma progestagens and corticosteroids were measured in Holstein- 
Friesian cows, half of which were kept in shade where the peak temperature reached $42-45^{\circ} \mathrm{C}$ (controls) and half in a cooler place where peak shade temperatures were $10-13^{\circ} \mathrm{C}$ lower (Stott \& Wiersma, 1973). The hormone levels were depressed in both groups as the temperature increased from May to September, but were always higher in the cooler, experimental group. Conception rate during this period was $31 \%$ in the experimental group and $14 \%$ in the control group. High humidity increased the effect of high temperature (Ingraham, Gillette \& Wagner, 1974) and the average temperature-humidity index of the 2 nd day before insemination was most related to conception.

Infection. In cattle, two infections generally considered to cause embryonic mortality, are Trichomonas foetus and Vibrio fetus, and the effect of the latter has been demonstrated experimentally (Adler, 1959). Attempts to demonstrate the existence of low-grade non-specific infection as a cause of embryonic death in repeat-breeder cows have not been successful, either by direct culture or by response to uterine infusions of antibodies (Ulberg et al., 1952).

Conditions at service. Insemination and slaughter experiments with cows have demonstrated that, as an ovum ages it retains the ability to be fertilized for a longer time than the ability to develop into a viable embryo (Barrett, 1948). These experiments covered a range of ovulation times from 2 to $28 \mathrm{hafter}$ the end of oestrus and it was shown conclusively that conception rates dropped due to the increased embryonic mortality when cows were inseminated later than $6 \mathrm{~h}$ after ovulation. This finding has significance for a country such as Israel where insemination service is not provided on the Sabbath.

Semen quality. The quality of semen has been shown to influence both fertilization rate and embryonic mortality, but findings have not always been consistent. Kidder, Black, Wiltbank, Ulberg \& Casida (1954) reported fertilization rates of $100 \%$ from bulls of high fertility and $71.4 \%$ from bulls of low fertility. Similar results were obtained by Bearden, Hansel \& Bratton (1956): $96.6 \%$ from bulls of high fertility $76.9 \%$ from bulls of low fertility. However the observations regarding embryonic losses differed. Kidder et al. (1954) found, on the basis of the difference between fertilization and non-return rates, that presumed embryonic losses were identical in heifers inseminated with spermatozoa from bulls of high and low fertility ranking, i.e. 24.2\%. Bearden et al. (1956) based estimated embryonic losses upon the difference between fertilization rates and actual slaughter findings 33 days after service: embryonic deaths were only $10 \cdot 5 \%$ for high-fertility bulls and $19 \cdot 2 \%$ for low-fertility bulls.

Hormonal imbalance. Although hormonal imbalance is frequently claimed to be connected with embryonic death, surprisingly little work has been published to establish to what extent this is true. The exception to this is progesterone, plasma levels of which have been shown to be similar in cows which are cyclic, which conceive or which do not become pregnant, until at-least about 16 days after ovulation (Shemesh, Ayalon \& Lindner, 1968; Pope, Mazlik, Ball \& Leaver, 1976). Urinary excretion rates of oestrogen during the first 9 days after mating showed an altered pattern in cows which returned to oestrus as compared with those that conceived (Randel, Gaverick, Erb \& Callahan, 1971). In a more recent study, Erb, Gaverick, Randel, Brown \& Callahan (1976) found no differences in excretion rates of urinary oestrogen, but plasma oestrogen levels were higher in fertile cows, particularly $12 \mathrm{~h}$ before oestrus and for 8 days afterwards. Plasma progesterone levels were similar, with slightly higher levels for fertile cows, before the LH increase and from Day 6 after ovulation and onwards. Erb et al. (1976) concluded that, compared with the fertile animals, infertile cows showed a high incidence of asynchrony, involving progesterone, $\mathrm{LH}$, oestrogen and urinary oestradiol-17 $\alpha$ levels most frequently before the day of oestrus. The pattern of hormone concentrations found is presented in Text-fig. 1.

Very contrasting results were found by our group at the Veterinary Institute in Israel (Ayalon, 1973). With a competitive protein-binding assay, plasma progesterone and oestrogen levels were measured daily, from the day of oestrus until slaughter on Day 7 after oestrus, in normal cows with normal embryos and in repeat-breeder cows with embryos showing clear signs of degeneration. The findings are shown in Text-fig. 2. The plasma progesterone levels were very similar in both types of cow, but the plasma oestrogen levels differed. In cows with abnormal embryos, values were higher 
on the day of oestrus and on Days 3 and 4 after insemination. However, although oestrogen concentrations of cows with normal embryos rose sharply on Day 6 and still more on Day 7 after service, in cows with abnormal embryos they did not rise on Day 6 in cows and dropped on Day 7.

The explanation for the very different patterns in hormone levels found in the two investigations is not apparent. However, Erb et al. (1976) compared values for pregnant cows and cows classified as non-pregnant on the basis of returns to oestrus. These non-pregnant cows would, therefore, include animals which had not conceived, as well as those with embryonic mortality. Our material was based

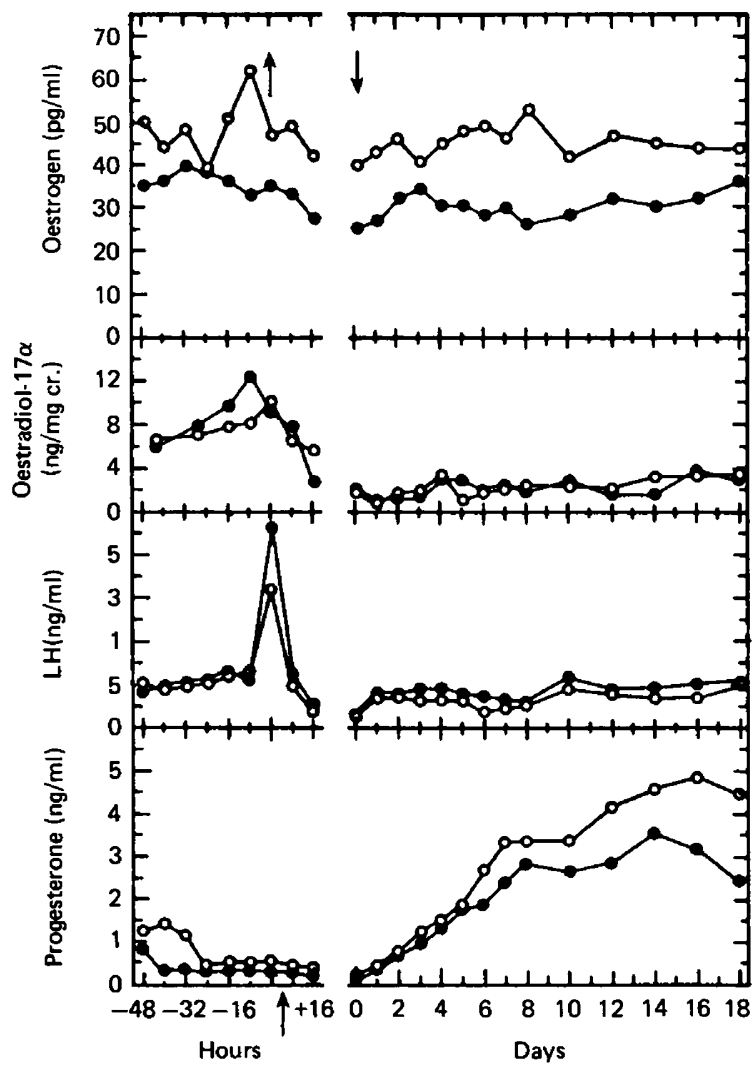

Text-fig. 1. Changes in blood plasma progesterone, LH and total oestrogen and in urinary oestradiol-17 $\alpha$ $48 \mathrm{~h}$ before to $16 \mathrm{~h}$ after preovulatory increases in LH $(\uparrow)$ and from 15:00 h on the day of ovulation $(\downarrow$ Day 0$)$ until Day 18 in fertile (O) and non-fertile (๑) cattle. (From Erb et al., 1976.)

upon the normality of embryos at slaughter. The significance of the hormonal findings in our study is supported by the parallel findings on embryonic mortality after planned slaughter of repeat breeders and normal cows (Ayalon et al., 1968; Ayalon, 1972) which show clearly that peak embryonic mortality also occurred on Day 7. Additional evidence, at testing to the critical physiological changes which become evident on Day 7 after service, are reflected in thestrikingchanges in ion concentrations in uterine flushings 6-8 days after insemination (see p. 490).

A more direct approach to the problem of hormonal imbalance and its relation to embryonic death was attempted by ovariectomy and various hormonal replacement treatments (Hawk, Brinsfield, Turner, Whitmore \& Norcross, 1963). First-service dairy heifers were ovariectomized 5, 6 or 7 days after insemination and given injections of progesterone alone or progesterone + oestrone. Both treatments gave good results, as shown by $73 \%$ normal embryos at slaughter $27-89$ days after insemination. By contrast, only $18 \%$ of repeat breeders, similarly treated, were pregnant at 38-62 days. 
Therefore, fertility was not improved by ovariectomy and injection of hormones that maintained early pregnancies in a high percentage of first-service cattle. Hawk et al. (1963) pointed out, however, that the results of the study do not rule out the possibility that imbalances of ovarian hormones could be involved in early embryonic mortality by acting at a time before ovariectomy was performed. Support for such a possibility has come from the studies of Miller \& Moore (1976a, b) and Moore \& Miller (1976). These workers ovariectomized ewes and treated them with various combinations of progesterone and oestradiol before and after embryo transfer. The treatment regimens simulated reproductive conditions in the intact ewe, those before oestrus, at oestrus, and in early pregnancy. Treatments were evaluated by their effects on parameters such as embryo survival and development and endometrial metabolism.

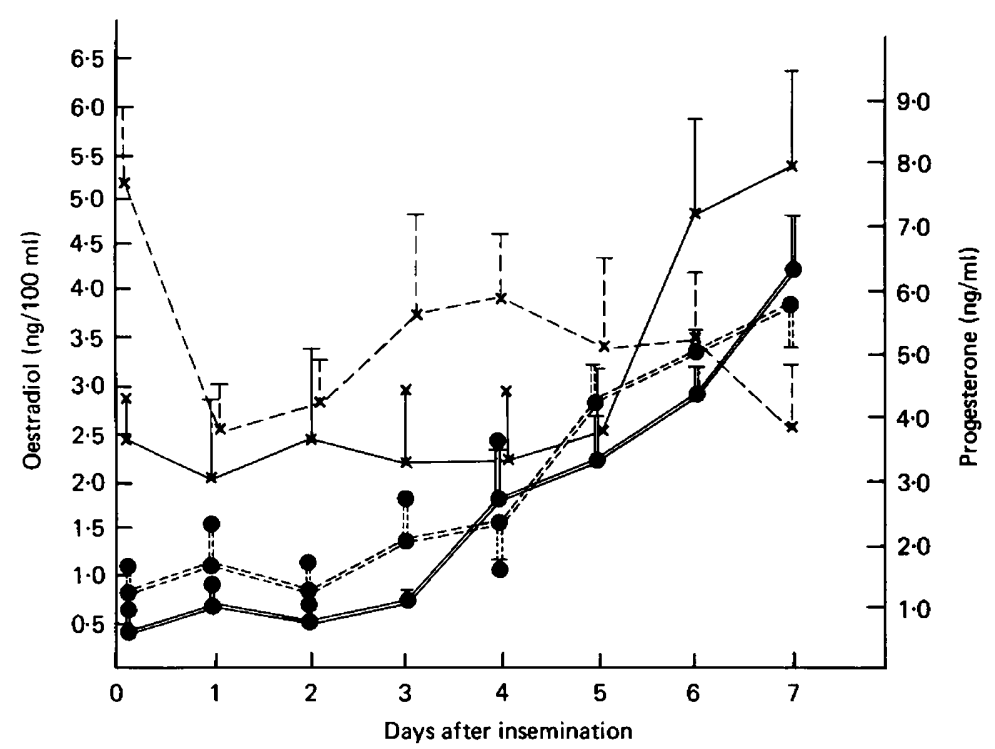

Text-fig. 2. Plasma progesterone $(\bullet)$ and oestradiol $(x)$ concentrations (mean \pm s.e.m.) in cows with normal $(-, n=11)$ or abnormal $(---, n=10)$ embryos.

Uterine environment. Embryo transfer experiments in the cow have demonstrated the critical importance of the state of uterine environment for the viability and development of the embryo (Rowson, Lawson, Moor \& Baker, 1972; Sreenan \& Beehan, 1974). Olds \& VanDemark (1957) suggested that uterine fluid composition may be controlled by ovarian hormones and Heap \& Lamming (1961) proved that this was so in the rat, rabbit, sheep and cow. In cyclic cattle, Lamothe \& Guay (1970) have compared the composition of endometrial secretions from normal and repeatbreeder cows: repeat breeders had lower uterine concentrations of $\mathrm{Na}, \mathrm{P}$, glucose and total protein on Days 5 and 11. Concentrations of $\mathrm{Ca}, \mathrm{K}$ and $\mathrm{Mg}$ were higher in repeat breeders and showed cyclic variations. Attempts to influence the electrolyte composition of uterine fluids by glucocorticoid therapy (Ibrahim, Guay \& Lamothe, 1972) and by a varied Ca/P ratio in the food (Lamothe, Bousquet \& Guay, 1976) were without significant effect. Roberts \& Parker (1974a) studied the nature of the macromolecular components of uterine fluid at different stages of the oestrous cycle and early pregnancy and found small amounts of uterine-specific proteins. In a further report, Roberts \& Parker (1974b) described an elevation of several glycosidases in uterine fluid as compared with serum, and concentrations rose in early pregnancy. No progesterone or oestrogen-binding activity was detected in the uterine proteins extracted. Linford \& Iosson (1975) produced evidence that the presence of the conceptus itself has a local effect on some biochemical parameters of the endometrium, examined between 25 and 70 days pregnancy. 
Our group at the Kimron Veterinary Institute has examined the levels of carbohydrate, total protein and several ions in the oviductal and uterine flushings from fertile and infertile cows during the period 6-8 days after to establish whether there are any service correlations of changes in concentrations of these constituents (Table 4) and embryonic mortality. Carbohydrate concentrations were similar for both types of cows and total protein levels were consistently higher in uterine flushings from normal cows, regardless of whether or not normal embryos were present. Striking differences were found in ion concentrations, particularly on Day 7 after oestrus. On this day, cows with abnormal ova had significantly higher concentrations of potassium, zinc, phosphorus and calcium. Especially impressive were the differences in calcium ions which rose on Day 7 in flushings from cows with abnormal embryos to more than 12 times the concentration of the ion in the uterine flushings from cows with normal embryos. The striking rise in all four ions on Day 7 would suggest a common cause for this change. The differences found in the uterine flushings were usually parallelled by similar changes in the oviductal flushings, thus indicating that the underlying mechanism is not a localized one. It may be related to the differences in the plasma oestradiol levels in repeat breeders with abnormal embryos which were mentioned earlier. Regarding total protein, no explanation is readily apparent for the trend to higher values in flushings from normal cows, regardless of whether a normal or abnormal embryo was present. However, it does indicate that there is a difference in the basic mechanism controlling the protein content of the uterine secretion in the two types of cows. This is apparently not influenced by progesterone, at least as reflected in levels in peripheral plasma which were very similar in both types of cows.

Table 4. Analysis of uterine flushing from cows of different reproductive status

\begin{tabular}{|c|c|c|c|}
\hline $\begin{array}{l}\text { Day after oestrus } \\
\text { or insemination }\end{array}$ & Unbred cows & $\begin{array}{l}\text { Cows with normal } \\
\text { embryos }\end{array}$ & $\begin{array}{c}\text { Cows with abnormal } \\
\text { embryos }\end{array}$ \\
\hline \multicolumn{4}{|c|}{ Total carbohydrate $(\mu \mathrm{g} / \mathrm{ml})$} \\
\hline Day 6 & $9.67 \pm 1.77(3)$ & $7 \cdot 33 \pm 1 \cdot 60(9)$ & $7 \cdot 10 \pm 0.94(5)$ \\
\hline Day 7 & $7 \cdot 83 \pm 1.30(8)$ & $7.91 \pm 0.52(11)$ & $6.63 \pm 0.64(12)$ \\
\hline Day 8 & $9 \cdot 10 \pm 1 \cdot 29(5)$ & $7.54 \pm 1.06(12)$ & $8.73 \pm 1.38(10)$ \\
\hline \multicolumn{4}{|c|}{ Mean K $(m g / 100 m l)$} \\
\hline Day 6 & $21 \cdot 44 \pm 1 \cdot 15(3)$ & $17 \cdot 46 \pm 1.61(8)$ & $18.66 \pm 0.51(5)$ \\
\hline Day 7 & $49.05 \pm 1.31(8)$ & $52 \cdot 40 \pm 3.41(10)$ & $58 \cdot 34 \pm 4 \cdot 84(7)$ \\
\hline Day 8 & $40 \cdot 45 \pm 1 \cdot 33(5)$ & $46 \cdot 78 \pm 2 \cdot 11(14)$ & $49.42 \pm 3.35(11)$ \\
\hline \multicolumn{4}{|c|}{ Mean P $(\mathrm{mg} / 100 \mathrm{ml})$} \\
\hline Day 6 & $3 \cdot 13 \pm 0.86(3)$ & $2.93 \pm 0.51(9)$ & $4.08 \pm 0.47(5)$ \\
\hline Day 7 & $7.07 \pm 1.05(8)$ & $4.86 \pm 0.70(14)$ & $6.98 \pm 0.58(5)$ \\
\hline Day 8 & $5.94 \pm 0.36(5)^{a}$ & $2.73 \pm 0.58(12)^{b}$ & $8 \cdot 20 \pm 1.00(11)^{a}$ \\
\hline \multicolumn{4}{|c|}{ Mean Zn $(m g / 100 \mathrm{ml})$} \\
\hline Day 6 & $4.00 \pm 0.00$ & $3 \cdot 32 \pm 0.10(9)$ & $4.04 \pm 0.59(5)$ \\
\hline Day 7 & $2.84 \pm 0.23(9)^{a}$ & $3.31 \pm 0.32(15)^{a}$ & $11.84 \pm 1.34(8)^{b}$ \\
\hline Day 8 & $3 \cdot 18 \pm 0.25(5)^{a}$ & $3.76 \pm 0.57(14)^{a}$ & $11.05 \pm 0.94(11)^{b}$ \\
\hline \multicolumn{4}{|c|}{ Mean Ca $(\mathrm{mg} / 100 \mathrm{ml})$} \\
\hline Day 6 & $5.98 \pm 1.05(3)^{c}$ & $10.78 \pm 0.98(9)^{d}$ & $12.32 \pm 0.32(5)^{d}$ \\
\hline Day 7 & $12 \cdot 15 \pm 4.76(8)^{a}$ & $14 \cdot 26 \pm 2 \cdot 21(13)^{\circ}$ & $178 \cdot 54 \pm 17 \cdot 38(8)^{b}$ \\
\hline Day 8 & $5.96 \pm 0.36(5)^{e}$ & $10 \cdot 50 \pm 1.43(10)^{f}$ & $10.24 \pm 0.96(10)^{f}$ \\
\hline
\end{tabular}

Days 6, 7 and 8

Total protein $(\mu \mathrm{g} / \mathrm{ml})$

(combined)

Normal cows

Repeat breeders

$179 \pm 19 \cdot 66(3)$
$115 \pm 1.69(13)$

$166 \pm 6.45(13)^{a}$

$114 \pm 1.48(21)^{b}$

$184 \pm 3 \cdot 50(4)^{a}$

$116 \pm 1.49(21)^{b}$

Values are mean \pm s.e.m., no. of cows in parentheses. Means with common superscripts are not significantly different. Those with differing superscripts differ significantly as follows:

$a, b=P<0.001 ; c, d=P<0.01 ; e, f=P<0.05$. 


\section{Conclusions}

What emerges from this review is that the most reliable method for studying fertility losses and embryonic mortality entails planned slaughter, supplemented by biochemical studies which seek to clarify what is happening. In recent years, the problem of embryonic mortality is being delineated more clearly and pertinent information has become available concerning the critical period for embryonic death and some of the concomitant biochemical changes that occur. More work is needed to confirm, clarify and extend the findings reported. This should include further work on the composition of the constituents of uterine fluid and factors influencing their nature and concentration, along with basic research on hormone requirements during early pregnancy, such as is being carried out in sheep in Australia, and reciprocal and other types of embryo transfer in normal cows, as well as in repeat breeders. It is my view and hope that we are on the threshold of a period of promising developments.

\section{References}

AdLer, H.C. (1959) Genital vibriosis in the bovine. An experimental study on the influence on early embryonic mortality. Acta vet. scand. 1, 1-11.

APPLEyARD, W.T. \& CoOK, B. (1976) The detection of oestrus in dairy cattle. Vet. Rec. 99, 253-256.

Ashton, G.C. \& Fallon, G.R. (1962) Beta globulin type, fertility and embryonic mortality in cattle. J. Reprod. Fert. 3, 93-104.

Ayalon, N. (1964) Sterilitas sine materia. Proc. 5th Int. Congr. Anim. Reprod. \& A.I., Trento, Section 4, pp. 47-80.

Ayalon, N. (1969) Final report of Research. Comparative studies of repeat breeders and normal cows and heifers. Kimron Veterinary Institute, Beit Dagan (Israel), pp. 1-92.

Ayalon, N. (1972) Fertility losses in normal cows and repeat breeders. Proc. 7th Int. Congr. Anim. Reprod. \& A.I., Munich, Vol. 1, pp. 741-744.

Ayalon, N. (1973) Annual Report of Research No. 2. Comparative studies of repeat breeders and normal cows. Kimron Veterinary Institute, Beit Dagan (Israel), pp. 1-51.

Ayalon, N., Weis, Y. \& Lewis, I. (1968) Fertility losses in normal cows and repeat breeders. Proc. 6th Int. Congr. Anim. Reprod. \& A.I., Paris, Vol. 1, pp. 393396.

BARRETT, G.R. (1948) Time of insemination and conception rates in dairy cows. $\mathrm{Ph} . \mathrm{D}$. thesis, University of Wisconsin. Cited by Casida (1950).

Bearden, H.J., Hansel, W. \& Bratton, R.W. (1956) Fertilization and embryonic mortality rates of bulls with histories of either low or high fertility in artificial breeding. J. Dairy Sci. 39, 312-318.

Bishop, M.W. (1964) Paternal contribution to embryonic death. $J$. Reprod. Fert. 7, 383-396.

Boyd, H. (1965) Embryonic death in cattle, sheep and pigs. Vet. Bull., Weybridge 35, 251-266.

Boyd, H. (1973) Oestrous cycles in Ayrshire cows before and after insemination. Vet. Rec. 92, 427-428.

Boyd, H., BaCsich, P., Young, A. \& MCCRACKen, J.A. (1969) Fertilization and embryonic survival in dairy cattle. Br. vet. $J .125,87-97$.
BRÄNNÄNG, E. (1954) Some causes of disturbances of fertility in cattle. Svensk Jordbr. Forsk. pp. 195-202. [In Swedish.] Cited by Reid et al. (1964).

Broster, W.H. (1973) Liveweight change and fertility in the lactating dairy cow. Vet. Rec. 93, 417-420.

Casida, L.E. (1950) The repeat breeder cow. Vlaams Diergeneesk. Tijdschr. 19, 273-283.

CasidA, L.E. (1956) Variations in maternal environment affecting pre-natal survival and development. Proc. 3rd Int. Congr. Anim. Reprod. \& A.I., Cambridge, Plenary Papers, pp. 19-25.

Casida, L.E. (1961) Present status of the repeat-breeder cow problem. $J$. Dairy Sci. 44, 2323-2329.

Committee on Reproductive Nomenclature (1972) Recommendations for standardizing bovine reproductive terms. Cornell. Vet. 62, 216-237

Conneally, P.M., Stone, W.H., Tyler, W.J., Casida, L.E. \& Morton, N.W. (1963) Genetic load expressed as fetal death in cattle. $J$. Dairy Sci. 46, 232-236. Cited by Boyd (1965).

DUNLAP, S.E. \& ViNCENT, C.K. (1971) Influence of postbreeding thermal stress on conception rate in beef cattle. J. Anim. Sci. 32, 1216-1218.

ERB, R.E. \& HoLTZ, E.W. (1958) Factors associated with estimated fertilization and service efficiency of cows. J. Dairy Sci. 41, 1541-1552.

ERB, R.E., GaVerick, H.A., Randel, R.D., Brown, B.L. \& Callahan, C.J. (1976) Profile of reproductive hormones associated with fertile and non-fertile inseminations of dairy cows. Theriogenology 5, 227242.

GrNTHER, O.J. (1968a) Utero-ovarian relationships in cattle: physiologic aspects. J. Am. vet. med. Ass. 153, 1656-1664.

GinTHER, O.J. (1968b) Utero-ovarian relationships in cattle: applied veterinary aspects. J. Am. vet. med. Ass. 153, 1665-1671.

HANLEY, S. (1961) Pre-natal mortality in farm animals. J. Reprod. Fert. 2, 182-194.

Hansel, W., Concannon, P.W. \& Lukaszewska, J.H. (1973) Corpora lutea of large domestic animals. Biol. Reprod. 8, 222-245. 
HAWK, H.W., TyleR, W.J. \& CASIDA, L.E. (1955) Effect of sire and system of mating on estimated embryonic loss. J. Dairy Sci. 38, $420-427$.

Hawk, H.W., Wiltbank, J.N., Kidder, H.E. \& Casida, L.E. (1955) Embryonic mortality between 16 and 34 days post-breeding in cows of low fertility. J. Dairy Sci. 38, 673-676.

Hawk, H.W., Brinsfield, T.H., Turner, G.D., WhitMORE, G.E. \& Norcross, M.A. (1963) Embryo survival in first-service and repeat breeder cattle after ovariectomy and hormone therapy. J. Dairy Sci. 46, 1397-1401.

Heap, R.B. \& Lamming, G.E. (1961) Studies of the uterine secretion of different species. Proc. 4 th lnt. Congr. Anim. Reprod. \& A.I., The Hague, Vol. II, pp. 300-311.

Hill, J.R., JR, LAmond, D.R., Henricks, D.M., Dickey, J.F. \& Niswender, G.D. (1970) The effects of undernutrition on ovarian function and fertility in beef heifers. Biol. Reprod. 2, 78-84.

Hoffman, B., Gunzler, O., Hamburger, R. \& Schmidt, W. (1976) Milk progesterone as a parameter for fertility control in cattle; methodological approaches and present status of application in Germany. Br. vet. J. 132, 469-476.

Ingraham, R.H., Gillette, D.D. \& Wagner, W.D. (1974) Relationship of temperature and humidity to conception rate of Holstein cows in sub-tropical climates. J. Dairy Sci. 57, 476-481.

Ibrahmim, M., Guay, P. \& Lamothe, P. (1972) Electrolytes of the blood and endometrial secretions of the cow following flucocorticoid therapy. Can. J. comp. Med. 36, 160-166.

JAINUDEEN, M.R. (1965) The "repeat breeder" cowa review. Ceylon vet. $J .13,10-16$.

JOUBERT, D.M. (1954) The influence of high and low nutritional planes on the oestrous cycle and conception rate of heifers. J. agric. Sci., Camb. 45, 164 172.

Kidder, H.E., Black, W.G., Wiltbank, J.N., Ulberg, L.C. \& CASIDA, L.E. (1954) Fertilization rates and embryonic death rates in cows bred to bulls of different levels of fertility. J. Dairy Sci. 37, 691-697.

LAING, J.A. (1949) Infertility in cattle associated with death of ova at early stages after fertilization. J. comp. Path. Ther. 59, 98-108.

LAING, J.A. (1952) Early embryonic mortality. Proc. 2nd Int. Congr. Anim. Reprod. \& A.I., Copenhagen, Section 2, pp. 17-34.

Lamothe, P. \& Guay, P. (1970) Electrolytes of bovine intra-uterine secretions during infertility sine materia. Can. J. comp. Med. 34, 167-176.

LAmothe, P., BousQuet, D. \& GuAy, P. (1976) Influence of exogenous phosphorus on uterine fluid composition. Theriogenology 6, 353-365.

LARSEN, H.J. \& LARSEN, H. (1956) Effect of nutritional level and food composition on economic efficiency, productive life and conception in dairy cows. Forsogslab. (Copenhagen) Beretn. No. 285. [In Danish.] Cited by Reid et al. (1964).

Linford, E. \& Iosson, J.M. (1975) A quantitative study of some lysosomal enzymes in the bovine endometrium during early pregnancy. J. Reprod. Fert. 44, 249-260.
Mares, S.E., Menge, A.C., Tyler, W.J. \& Casida, L.E. (1961) Genetic factors affecting conception rate and early pregnancy loss in Holstein cattle. J. Dairy Sci. 44, 96-103.

Marion, G.B., SMith, V.R., Wiley, T.E. \& BarRetT, G.R. (1950) The effect of sterile copulation on time of ovulation in dairy heifers. $J$. Dairy Sci. 33, 885-889.

McFeely, R.A. \& Rajakoski, E. (1968) Chromosome studies on early embryos of the cow. Proc. 6th Int. Congr. Anim. Reprod. \& A.I., Paris, Vol. II, pp. 905907.

MENGE, A.C. (1969) Early embryonic mortality in heifers isoimmunized with semen and conceptus. J. Reprod. Fert. 18, 67-84.

Menge, A.C., Mares, S.E., Tyler, W.J. \& Casida, L.E. (1962) Variation and association among postpartum reproduction and production characteristics in Holstein-Friesian cattle. J. Dairy Sci. 45, 233241.

Miller, B.G. \& Moore, N.W. (1976a) Effects of progesterone and oestradiol on endometrial metabolism in the ovariectomized ewe. J. Reprod. Fert. 46, 535536, Abstr.

Miller, B.G. \& Moore, N.W. (1976b) Effects of progesterone and oestradiol on endometrial metabolism and embryo survival in the ovariectomized ewe. Theriogenology 6, 636, Abstr.

Moore, N.W. \& Miller, B.G. (1976) Progesterone and oestrogen requirements for the survival of embryos in the ovariectomized ewe. J. Reprod. Fert. 46, 536537, Abstr.

Olds, D. \& Vandermark, N.L. (1957) Composition of luminal fluids in bovine female genitalia. Fert. Steril. 8, 345-354.

Pope, G.S., Mazlik, I., Ball, P.J.H. \& Leaver, J.D. (1976) Use of progesterone concentrations in plasma and milk in the diagnosis of pregnancy in domestic cattle. Br. vet. J. 132, 497-506.

RaNDEL, R.D., GaVerick, H.A., ERB, R.E. \& Callahan, C.J. (1971) Reproductive steroids in the bovine. IV. Urine excretion rates from 0 to 9 days after breeding in fertile and nonfertile cows. J. Anim. Sci. 32, 1183-1189.

Rausch, W.H., LudWICK, T.M., WESEl, D.F., RichardSON, D.O., RADER, E.R., BRUM, E.W., HiNES, H.C., Fowler, A.K. \& Plowman, D. (1963) Association of bovine transferrin types as determined by disc electrophoresis, with fertility and production. $J$. Dairy Sci. 46, 648, Abstr.

ReID, J.T., Loosli, J.K., Trimberger, G.W., Turk, K.T., Asdell, S.A. \& Smith, S.E. (1964) Causes and prevention of reproductive failures in dairy cattle. Bull. Cornell Univ. agric. Exp. Stn. 987, 3-31.

Roberts, G.P. \& PARker, J.M. (1974a) Macromolecular components of the luminal fluids from the bovine uterus. J. Reprod. Fert. 40, 291-303.

ROBERTS, G.P. \& PARKeR, J.M. (1974b) Investigation of enzymes and hormone-binding proteins in the luminal fluid of the bovine uterus. J. Reprod. Fert. 40, 305-313.

Rowson, L.E.A., Lawson, R.A.S., MooR, R.M. \& Baker, A.A. (1972) Egg transfer in the cow: synchronization requirements. $J$. Reprod. Fert. 28, 427431. 
Shemesh, M., Ayalon, N. \& LindNer, H.R. (1968) Early effect of conceptus on plasma progesterone level in the cow. J. Reprod. Fert. 15, 161-164.

Sreenan, J. \& BeehaN, D. (1974) Egg transfer in the cow: pregnancy rate and egg survival. $J$. Reprod. Fert. 41, 497-499.

StotT, G.H. (1961) Female and breed associated with seasonal infertility variation in dairy cattle. $J$. Dairy Sci. 44, 1698-1704.

StotT, G.H. \& Williams, R.J. (1962) Causes of low breeding efficiency in dairy cattle associated with seasonal high temperatures. J. Dairy Sci. 45, 1-7.

StotT, G.H. \& Wiersma, F. (1973) Climatic thermal stress, a cause of hormonal depression and low fertility in the bovine. Int.J. Biometeorol. 17, 115-122.

TANABE, T.Y. \& Almouist, J.O. (1953) Some cause of infertility in dairy heifers. J. Dairy Sci. 36, 586, Abstr.
Tanabe, T.Y. \& Casida, L.E. (1949) The nature of reproductive failure of cows of low fertility. $J$. Dairy Sci. 32, 237-246.

Ulberg, L.C., Black, W.G., Kidder, H.E., McDonald, L.E., Casida, L.E. \& McNutT, S.H. (1952) The use of antibiotics in the treatment of low fertility cows. J. Am. vet. med. Ass. 121, 436440.

VANDEPLASSCHE, M. (1968) La mortalite embryonnaire et son diagnostic. Proc. 6th Int. Congr. Anim. Reprod. \& A.I., Paris Vol. I, pp. 347-391.

Wiersma, F. \& STOTT, G.H. (1966) Micro-climate modification for hot weather stress relief of dairy cattle. Trans. Am. Soc. agric. Engrs 9, 309-313.

Wiersma, F. \& StotT, G.H. (1969) New concepts in the physiology of heat stress in dairy cattle of interest to engineers. Trans. Am. Soc. agric. Engrs 12, 130132. 